\title{
A History of Universalism: \\ Conceptions of the Internationality of Science from the Enlightenment to the Cold War
}

\author{
Geert J. Somsen
}

Published online: 24 September 2008

(C) The Author(s) 2008. This article is published with open access at Springerlink.com

\begin{abstract}
That science is fundamentally universal has been proclaimed innumerable times. But the precise geographical meaning of this universality has changed historically. This article examines conceptions of scientific internationalism from the Enlightenment to the Cold War, and their varying relations to cosmopolitanism, nationalism, socialism, and 'the West'. These views are confronted with recent tendencies to cast science as a uniquely European product.
\end{abstract}

Keywords Universalism · Internationalism · Nationalism ·

Historiography of science

\section{Introduction}

The idea of Europe as the 'cradle of modern science' is gaining popularity in unexpected circles. Many EU enthusiasts wish to complement the process of political and economic integration by a growing sense of a common European culture. And some of them have embraced science as a major constituent of a shared European heritage. Wasn't the Scientific Revolution the product of collective European endeavour? And isn't modern science a uniquely European achievement, unrivalled by historical developments in other times and places? (Lecourt 1993) ${ }^{1}$ Promoters of a European consciousness eagerly answer in the affirmative and squarely identify science with Europe. In the words of the Crown Prince of The Netherlands: 'Science is an important bearer of the social and cultural identity of

\footnotetext{
1 For a critical response see (Schaffer 2000).
}

G. J. Somsen ( $₫)$

History Department, Universiteit Maastricht, P.O. Box 616, 6200 MD Maastricht, The Netherlands e-mail: g.somsen@history.unimaas.nl 
Europe that (...) distinguishes itself from other societies and earlier cultures by its rationality' (HRH the Prince of Orange 2006, p. 101). ${ }^{2}$

While such claims may be politically timely, historiographically they are quite out of touch. Over the last two decades, historians of science have paid great attention to the places where science is practiced, and have recognized the significance of local contexts for the production of knowledge. ${ }^{3}$ But these settings are generally of a much smaller size than Europe as a whole. Typically they range from laboratories to places like courts, cities, and even national institutions-but seldom to anything larger in scope. Europe is simply too big and too diverse to be a meaningful context. As the 'geographer of science' David Livingstone observed, the idea of a seamlessly European science 'fails to take seriously enough the regional geography of science' (Livingstone 2003, p. 91). ${ }^{4}$

Yet, the current emphasis on local contexts is not only opposed to a European picture, but also to the long-standing notion of science as inherently universal. In fact, the localist perspective has developed precisely as a reaction against such universalism: the idea that science is independent of the place where it is practiced (because of the universality of its knowledge or method), and that scientific practitioners are automatically united in a single global pursuit-a model of peaceful cooperation. Already in the 1960s Brigitte Schröder-Gudehus offered compelling evidence against this ideal-picture, showing that in times of international tension, scientists have been at least as nationalist and uncooperative as ordinary citizens (Schröder-Gudehus 1966, 1978). Not much later Jean-Jacques Salomon concluded that modern science is far too wrapped up with state institutions to transcend national interests, despite its universal epistemic basis (Salomon 1971). In the decades that followed, studies inspired by the sociology of scientific knowledge showed even the categories at this basis (what counts as fact? what is a demonstration?) to be locally constituted, and the wider 'travel' of knowledge became something to be explained as a material and embodied accomplishment rather than the frictionless result of science's inherent universality (Shapin 1995, pp. 304-309).

But while the reality of scientific universalism has been rejected, there has been no denial of its power as self-representation. Science may not be inherently universal, but scientists have often viewed their enterprise in such terms. Since the Enlightenment, the universal character of science has been proclaimed innumerable times-for various reasons, and in a range of different contexts. And in accordance with these varying circumstances, the meaning of the concept itself has historically changed. A number of historians have analysed how scientific universalism has been understood in

\footnotetext{
${ }^{2}$ For similar views see (Office for Official Publications of the European Communities 2006). I am indebted to Kostas Gavroglu for this reference.

3 Localist historiography has become so widespread that the literature is too vast to cite. General and methodological overviews include (Ophir and Shapin 1991; Shapin 1995; Golinski 1998, Chap. 3; Livingstone 2003).

4 The idea of a homogeneous European science has also been questioned by scholars of STEP (Science and Technology in the European Periphery-see http://www.cc.uoa.gr/step/) while histories of colonial settings have challenged the European boundaries of science. See, e.g. (MacLeod 2000a, 2005).
} 
some significant periods and contexts. ${ }^{5}$ But what is still lacking is a long-term perspective that highlights its general historical variability. Such a perspective can show, for example, how the rise of nationalism has affected how science was perceived to be universal, and clarify what the term 'inter-national' has meant. A longue-durée view may also reveal whether 'universal' has been simply a codeword for 'Western', and how the conception of science as 'European' fits in the history of universalism. This paper aims to contribute to these goals by outlining predominant notions of scientific universalism from the late Enlightenment to the early Cold War.

\section{The Republic of Letters}

Scientific universalism found one of its most important expressions in the ideal of the 'Republic of Letters', a concept widely promoted by savants in the early modern period (Goldgar 1995; Goodman 1994). The pursuit of knowledge, according to this ideal, brought people of various creeds and countries together, and inspired a loyalty that stood above religion, family or nation. Men of learning were supposed to form a cosmopolitan Republic that transcended national rivalries and conflicts. Needless to say, such rivalries did often occur in practice, but to call the Republic of Letters an inconsequential ideal would be to underestimate its power as a shared value. Savants did feel obliged to act in an open, cooperative manner and expected others to do likewise. So while England and France were at war for much of the eighteenth century, their men of science continued to share news and observations, and the Royal Society and Académie des Sciences kept electing honorary members across the Channel. Leaders of overseas expeditions, like Thomas Cook and Alexandre Guy Pingré, even received assistance from 'enemy' navy officers. That science was supposed to rise above war and international conflict was even recognized on the battlefield itself. ${ }^{6}$

Whether the Republic of Letters was seen as a 'European' community has proved hard to analyse. It is true that most of its members lived in Europe, but Americans like Benjamin Franklin and Thomas Jefferson were certainly included-also after their country ceased to be a colony of Britain. Women, Jews, and members of other religious minorities were routinely excluded, but at the same time natives of Morocco and Libya could be elected Fellows of the Royal Society, even though this did not necessarily merit them savant status. ${ }^{7}$ The Republic was certainly not as 'open to everybody' as its promoters would have it, but it seems that until the general rise of the nation-state, exclusion followed the lines of religion and social standing rather than nationality (Goldgar 1995, pp. 3-7; Daston 1991; Shapin 1998/ 1999). Perhaps the most precise statement would be that the Republic of Letters

\footnotetext{
5 Apart from both books by Schröder-Gudehus (1966, 1978): (Forman 1973; Daston 1990; Crawford et al. 1993; Widmalm 1995; Otterspeer and Schuller tot Peursum-Meijer 1997; Metzler 2000; Krige and Barth 2006).

6 The classical but contested work on this is (de Beer 1960). See also (Daston 1990, p. 98; Crosland 1995).

7 Mohammed Ben Ali Abgali, ambassador of the emperor of Morocco (elected 1726), and Cassem Algiada Aga, ambassador of the kingdom of Tripoli (elected 1728), were among several non-European Fellows within Britain. On British Fellows overseas, see (Home 2002).
} 
coincided with 'the civilized world', which in practice excluded most non-western parts of the globe, but in principle was geographically inclusive.

\section{Scientific Nationalism}

A major change in the cosmopolitanism expressed in the ideal of the Republic of Letters occurred during the late eighteenth century. After the French Revolution, patriotic values began to be associated with the pursuit of knowledge. Whereas the fruits of science used to be reaped by all of humanity, during the Napoleonic consulate and empire, its accomplishments were increasingly presented in terms of national prestige (Daston 1990). The emperor himself designed medals, ceremonies, and even uniforms for savants whose achievements added to their own fame as well as to that of their nation's. The Institut National repeatedly trumpeted 'la gloire de la patrie', emphasizing France's scientific superiority, and hence also justifying the lootings of natural history collections in occupied regions. Military victory was linked to scientific success. Learned men in other countries reacted with disapproval to the sudden change of values, or were sometimes simply surprised-like Joseph Banks, who had pleaded for the release of an imprisoned French naturalist qua naturalist, and was thanked for his support of the French national cause (Daston 1990, pp. 99-101). In the course of the nineteenth century, however, these reservations ceded, and science was increasingly combined with nationalism, also outside of France. $^{8}$

Scientific nationalism developed most dramatically in the German states after 1815. From its incipience, German nationalism was built on the notion of a common Kultur, of which Wissenschaft was an important part. ${ }^{9}$ Although practitioners of the humanities (Geisteswissenschaftler) were generally seen as the prime bearers of this culture, their colleagues in the natural sciences aspired to be regarded similarly, and with some success. The Gesellschaft Deutscher Naturforscher und Ärzte (GDN̈̈, Association of German Scientists and Physicians) was known as a symbol and advocate of a united German nation when that nation was still politically divided over many principalities. Liberal scientists like Hermann Helmholtz, Karl Ludwig, and the young Emil Du Bois-Reymond supported the 1848 Revolution and the 'Professors' Parliament' in Frankfurt, which aimed at a single unified nation-state. Their belief in the fundamental unity of science was closely related to their aspirations for national unity, and when this was finally achieved under Bismarck, these sentiments did not fade (Galison forthcoming). ${ }^{10}$ By the late nineteenth century, Wissenschaft was still seen as a crucial component of German culture, and advancements made by German scientists were regarded as reflecting the greatness of the nation-just like economic and military achievements did (McCormach 1974; Daston 1998, pp. 72-73). Not only had the material role of science in the country's

\footnotetext{
${ }^{8}$ On subsequent developments of scientific nationalism in France, see (Fell 2002). The volume in which this article appeared offers an excellent overview of the historiography of scientific nationalism. See especially the editors' introduction (Jessen and Vogel 2002).

9 On German science and nation-building, see (Lenoir 1997; Cahan 1989; Johnson 1990).

${ }^{10}$ On the more radical Rudolf Virchow, who would dissent under Bismarck, see (Goschler 2002).
} 
industry and armed forces increased, also ideologically science was increasingly associated with Germany's national strength.

Scientific nationalism also prospered in other countries. In 1830, Charles Babbage looked with envy to the French patriotic support of science when he wrote his Reflections on the Decline of Science in England (Daston 1990, p. 112). Later in the century, the good of the nation and the British Empire became common themes in public projections of the value of science (Turner 1980). ${ }^{11}$ Even though 'Englishness' continued to be associated with a liberal-humanist education, natural scientists proclaimed that they could edify the nation just as well, or even better. ${ }^{12}$ In Hungary, where Magyar nationalism was officially accepted after 1867, scientific achievements were fully integrated into the glorified national heritage. ${ }^{13}$ And even a small country like the Netherlands developed a late but full-fledged version of scientific nationalism. Not only was the celebrated work of H. A. Lorentz and J. H. van 't Hoff described as typical 'physics of the fatherland' and specifically 'Dutch chemistry', but the whole blossoming period of Dutch science around 1900 was understood in nationalist terms (van Lunteren 2004; Oosterhoff 1984; van Deventer 1887). It was called 'the Second Golden Age' as if it were a repetition of the first 'Golden Age' of the seventeenth century, the nation's alleged Gründerzeit (van Berkel 1998, pp. 149-150). Speakers at the Nederlandsch Natuur-en Geneeskundig Congres (Netherlands Scientific and Medical Congress), a Dutch version of the GDNÄ, even claimed that the national character (dispassionate, patient, precise and persevering) made Dutchmen exceptionally well-suited for scientific work. Here scientific achievement was not only described, but also explained in nationalist terms (Visser 1991). ${ }^{14}$

\section{Olympic Internationalism}

Yet, while scientific nationalism became widespread by the turn of the twentieth century, the supranational qualities of science did not cease to be stressed. What used to be the cosmopolitan Republic of Letters now became 'the international scientific community', with a shift in meaning from a brotherhood of individuals to an association of nations. But the peace-promoting effects of the scientific community continued to be emphasized, and its territory was still identified with 'the civilized world', or with 'Christendom', even in nonreligious meanings. For secularist writers like Andrew Dickson White and Thorstein Veblen, Christendom was the space once dominated by Christianity, and now the domain of modern civilization where science reigned supremely (White 1893; Veblen 1918).

\footnotetext{
11 See also several of the essays in (MacLeod 1996, 2000b).

12 E.g. (Hill 1937). See further (Mayer 2000a, b).

13 Any walk through the statue-laden city of Budapest can testify to this.

14 In a similar vein, contemporaries like Pierre Duhem and J. T. Merz argued that different nations have different styles in science. This theme of national styles has persisted, but current analysts like Jonathan Harwood explain them in institutional terms rather than on the basis of national character. See e.g. (Harwood 1987).
} 
At the same time, the international scientific community was increasingly institutionalized, first in the novelty of the international conference, and later in a growing number of international unions in specific scientific disciplines. No less than twenty three scientific unions were founded between 1860 and 1899, when the International Association of Academies was created to top them all (Speeckaert 1957, p. xiii; Rasmussen 1990; Schroeder-Gudehus 1990). So rapid was the multiplication of international institutions that catalogues were written to keep track of the fervent development, which was itself sometimes called l'internationalisme scientifique (e.g. Eijkman 1910, 1911; Speeckaert 1957).

It may at first appear paradoxical that this growth in the international organization of science occurred simultaneously with scientific nationalism, but in fact the two went hand in hand (Schroeder-Gudehus 1966, pp. 41-62; Forman 1973; Metzler 2000, pp. 33-83). While the new institutions were presented as vehicles for international cooperation, they were also meant to assess and acknowledge national scientific accomplishments. National achievements, after all, can only be measured by international standards, so some form of international organization was required for them to be recognized at all. Paul Forman has aptly compared this situation to the practice of the Olympic Games, which are supposed to advance both international fraternization and national victory and pride-see the national hymns and flags at the winners' podium (Forman 1973, p. 154). Likewise in science around 1900, international competition served to demonstrate national accomplishment and, at the same time, international brotherhood and national triumphs were celebrated. Scientific internationalism was not a counterforce to nationalism, but effectively channelled and facilitated it.

The First World War gravely upset international relations in science, yet it did not destroy the Olympic model through which those relations were generally perceived. ${ }^{15}$ Shortly after the outbreak of the War, 93 prominent German intellectuals signed a manifesto An die Kulturwelt! (To the Civilized World!), in which they declared loyalty to their country and tried to justify its military actions (von Ungern-Sternberg and von Ungern-Sternberg 1996). ${ }^{16}$ Among the signers were many important academics, including active promoters of international cooperation, like Wilhelm Ostwald. But their patriotism was not the result of a sudden reversal of values (Schroeder-Gudehus 1990, pp. 137-138). It had been part and parcel of an internationalism that already included passionate forms of nationalism, and that regarded scientific achievement as a manifestation of national greatness, comparable to military success.

This is not to say that scientists across the frontlines appreciated the patriotic declaration. Very soon after the manifesto appeared, several English and French scholars published dismissive responses to the German professors. Their objection was not that their counterparts 'across the Rhine' had expressed loyalty to their country-the British and French felt a similar urge to serve their nations. What

\footnotetext{
15 Much has been written on the rift in international relations in science during and after the First World War. See (Schroeder-Gudehus 1966; Widmalm 1995; Otterspeer and Schuller tot Peursum-Meijer 1997; Metzler 2000; Kevles 1971; Grau 2000; MacLeod 2000c).

16 The Aufruf's authors actually defended their case by appealing to internationalist values.
} 
upset them was that German nationalism seemed to be violating the norms of international conduct - quite literally, because the German armies were thought to have broken international laws of warfare. The manifesto had denied this, just as it had denied a whole series of alleged war crimes that were taken as established facts on the Allied side-the wilful destruction of the university library of Louvain, for example. In Allied eyes, this explicit denial of fact demonstrated that the German scientists were even willing to sacrifice truth for their overwhelming nationalism, and hence destroy their own credibility. The Germans saw this differently, and were in turn disturbed by the arrogant chauvinism of Allied scientists (Otterspeer and Schuller tot Peursum-Meijer 1997, pp. 23-25). Only a few, such as Albert Einstein, rejected nationalism altogether (Nicolai et al. 1996). Most adhered to Olympic internationalism, which gave room for patriotism if kept within the limits of proper international conduct. Their accusation was not that their counterparts played the Olympic game, but that they tried to win it by breaking the rules.

These perceptions persisted after the war, creating a situation of long-lasting gridlock. Scientists from Allied nations, especially France and Belgium, felt that the Germans had so deeply violated the norms of international relations (in science as on the battlefield), that it was impossible to resume cooperation. Accordingly, German scientists were banned from international unions and from the International Research Council (IRC), the new all-encompassing organization, set up around the time of the Treaty of Versailles (Kevles 1971). Many German scientists felt that their Allied colleagues were abusing military victory to dominate the scientific world, which was not a far-fetched idea since the IRC came directly out of the Inter-Allied Research Council, an organization created during the war for military purposes (Kevles 1971, pp. 51-57). ${ }^{17}$ But after years of protracted discussions, the IRC decided to stop the exclusion of German scientists and, in 1926, invited Germany to join as a member. The Germans, however, declined. One reason was the way in which the IRC had worded their invitation. As Fritz Haber explained,

We know very well that we have lost the war and that both politically and economically we no longer belong to the leaders of the world. But scientifically we still believe to be among the nations that can claim a leading position. Whether this claim is acknowledged is hard to tell from an invitation of the same form as that which has been sent to Siam. ${ }^{18}$

For Haber, national greatness could be manifested in military, economic or scientific ways, and the point of international organizations was to recognize such greatness. This is where the IRC had failed, because it had treated Germany similarly to Siam. Despite the war and its troublesome aftermath, scientific internationalism was still conceived in terms of the Olympic model.

\footnotetext{
17 Moreover, delegates to the IRC were appointed by their respective governments, and the number of national representatives depended on the size of a country's population rather than its scientific merit. See (Jones 1960, p. 171).

18 Quoted in Otterspeer and Schuller tot Peursum-Meijer (1997, p. 162) (my translation).
} 


\section{Socialist Internationalism}

Yet the Olympic model would fade. What made it give way was not the war and the tensions it created. It was the rise between the two world wars of a wholly different kind of scientific internationalism-one that espoused a different relation between science and nationalism and a different role of science in the world.

Some of this change was foreshadowed before the Great War by the Belgian scientist and historian of science George Sarton. Sarton was not opposed to nationalism per se, but he believed that what was important about science was not its national, but its international base. No discovery was ever made in isolation, and no nation made any significant advance without contributions from others. Science was an activity of mankind as a whole, and that unique universality made it the backbone of civilization (Theunissen forthcoming; Thackray and Merton 1972). Sarton founded the journal Isis with the explicit aim of demonstrating and celebrating this fundamentally international character. 'But Alas!', he wrote in the first issue,

If science is in essence international, sometimes scientists are not. Too often, the generosity which science should confer to them, is suffocated by their chauvinist and nationalist tendencies. Isis will work in the other direction, underlining the lessons of tolerance and wisdom that history teaches so abundantly; Isis will denounce on every possible occasion the imperialist tendencies that some scientists try to impose on the science of their country or of their race. (Sarton 1913, p. 44) ${ }^{19}$

What Sarton tried to show was the global nature of scientific endeavour. The early issues of Isis not only presented articles on Paracelsus and 'Three English men of science', but also on Hindu geometry, Arab mineralogy, and Japanese algebra (e.g. Whetham and Whetham 1913; Smith 1913; Ruska 1913; Mikami 1914). In this effort, Sarton was later joined by scientist-historians like Joseph Needham and J.D. Bernal, who regarded science as a human faculty that was present in all civilizations. Science, in Needham's words, was not Western but 'ecumenical', flowing from sources all over the globe into one great river of truth (Bray 1996; Low 1998, pp. 1-2). ${ }^{20}$ His, as well as Bernal's and Sarton's accounts were not national or European, but 'world histories' of science.

Another major turn away from Olympic internationalism was instigated by the English writer H. G. Wells. Wells was famous not only for his science fiction, but also for his political commentaries, in which science played an equally central role. In Wells' view, the evils of his day (from social injustice to world war) were the result of a lack of scientific knowledge among the general public and the leaders of government. Since people were hardly ever taught objective facts about the world, but instead indoctrinated by teachings like nationalist history, it was no wonder that catastrophes such as the Great War occurred. Wells hoped that in the course of time

\footnotetext{
19 Sarton (1919) rejected cosmopolitanism, stressing that he preferred an internationalism that presupposed strong nations. On the whole, however, he emphasized the international and internationalizing, rather than the national, character of science.

20 The global perspective is continued in (McClellan and Dorn 1999).
} 
education would become scientific, and a scientific mentality would begin to guide politics. The current system of nation states would then be dispensed with and mankind would move toward a global society. In the 'World State' which Wells vehemently promoted, scientific procedures would direct government and divisions between nations would no longer exist (Partington 2003; de Wilde and Somsen forthcoming). For Wells, the progress of science was directly coupled to the regress of nationalism, and in this his internationalism markedly differed from the Olympic model. Literally speaking, Wells' version was not even 'inter-national' anymore, but generally cosmopolitan.

In the 1930s, Wells' ideals of scientific government and international integration were also adopted by what has become known as 'the scientific Left' in Britain. ${ }^{21}$ Communist scientists like Bernal, Needham, and J. B. S. Haldane, and more moderate reformers such as Julian Huxley proclaimed that scientific planning could solve society's problems much better than regular politics. For them, science was not just the study of nature, but a general attitude and way of thinking that formed a reasonable guide in any political area, including international affairs. Most of them regarded socialism very similarly: as a rational approach to society. Not all went as far as Bernal, who claimed that essentially science is communism, and that therefore the Soviet Union was the model of a scientific society (Bernal 1939, p. 415). But most left-wing scientists did agree that science and socialism shared their most important values: the relief of human misery, transcendence of nation and class, progressivism, internationalism.

While leftist views soon dominated British discourse on science, similar developments took place in the U.S., France, the Netherlands, and even Republican Spain (Kuznick 1987; Bensaude-Vincent 1987; Petitjean (unpublished paper); Salmón and Huertas forthcoming; Somsen 2001). The internationalist movement became international, and gained coherence with the rise of a common enemy in Nazi Germany. Many left-wing scientists regarded national socialism as not only politically objectionable, but also deeply at odds with the values of science-a view that they saw confirmed by the Nazis' expulsion of Jewish scientists. When this wave of refugees arrived in Western Europe and the U.S., feelings of solidarity were further enhanced, and scientific internationalism seemed more urgent than ever (Koch and Platt 1993).

How the notion of internationalism had changed with respect to its earlier incarnations can be seen in the official resolutions of the International Council of Scientific Unions (ICSU), the successor to the IRC. In 1934 and 1937, the ICSU adopted two proposals from the socialist-dominated Amsterdam Academy of Sciences, the second carrying signatures of left-wing scientists from all over the world. $^{22}$ Both proposals were responses to the tensions created by Nazi Germany, and called upon the 'brotherhood of scientists' to maintain international relations

\footnotetext{
21 The term is from (Werskey 1988). See also (Werskey 1971; McGucken 1984).

22 'Proposal by the Royal Academy of Sciences, Amsterdam,' in Lyons (1935, pp. 16-17); Untitled resolution, in (Stratton 1937, p. 17). The signatures were given to a separate document, accompanying the latter proposal: 'Memorandum Concerning a Proposal for the Appointment of a Committee for Investigating the Social Responsibilities of Science', National Archives of North-Holland (Haarlem), files of the Koninklijke Akademie van Wetenschappen, 64, entry 455.
} 
and keep exemplifying peaceful cooperation. In itself such an appeal was hardly new, yet the way in which it was framed differed from older forms of internationalism. While in the Olympic model, science reflected the greatness of a nation, now it was presented as an antidote to nationalist sentiments. Both proposals warned against excessive nationalism and associated it with tribal instincts, 'unsound creeds and prejudices', and barbarism. Also, the perception of science-military relations was different. Whereas in the Olympic model, military power was on a par with scientific achievement, now their values were diametrically opposed. If science stood for argument and reason, militarism meant authority and brute force. Hence,

The old historical tendency which considered the military and the naval organization as the most important factor of a nation and as the prime expression of its force, should nowhere find support among scientific workers, as it is contrary to our present idea of cultural advance. ${ }^{23}$

Most fundamentally, the conception of science itself had changed. In the Olympic framework, science was viewed as a cultural good, comparable to philosophy or art. In the socialist scheme of things, science was primarily presented as an instrument to solve the problems of society. Both ICSU proposals spoke extensively about pressing economic and social issues, and presented science as their ultimate solution, if only it could be organized internationally.

\section{Science and World Order}

The Second World War silenced socialist internationalism on the continent, but it survived and thrived in the UK. Scientific research became part of the British war effort, and left-wing scientists proclaimed that this form of intensive use of science (especially for civil purposes) should continue to exist in peacetime. ${ }^{24}$ The British Association for the Advancement of Science organized a series of conferences promoting scientific approaches to social problems, the largest of which took the subject to a global scale. 'Science and World Order' was a high-profile meeting with enormous press-coverage, where hundreds of British scientists, Nazi-refugees, politicians, and foreign diplomats discussed how to build a new society after the war with the aid of scientific methods and in keeping with scientific values ('Science and World Order' 1942). One of the main topics was scientific internationalism, a subject that, according to a conference report, could have been taken for granted had it not been threatened by Nazi Germany. The Nazis had not only expelled Jewish scientists, but even denied the internationality of science and introduced the idea of an exclusively Aryan physics. True science, the report stated, could not do

\footnotetext{
23 'Memorandum Concerning a Proposal for the Appointment of a Committee for Investigating the Social Responsibilities of Science', National Archives of North-Holland (Haarlem), files of the Koninklijke Akademie van Wetenschappen, 64, entry 455, p. 4.

24 For a compelling critique of this rhetoric, see (Edgerton 1966).
} 
otherwise than condemn such nationalist perversions (Crowther et al. 1942, pp. 129-138).

Aryan physics in fact never gained much ground in Nazi Germany, but it did become an important resource for Allied war propaganda. The journal Nature condemned it from the start, and Robert Merton used it as a counterexample against which he formulated his norms of science (Hollinger 1983). ${ }^{25}$ Aryan chauvinism was contrasted with scientific universalism, and the Nazis' ideological travesty of physics helped to stage 'free science' as a natural ally of democracy (e.g. 'Science and World Order' 1942, pp. 115-116). These associations delivered another blow to scientific nationalism, which now was not only rejected by socialist scientists, but became a potentially suspect position for anybody in the West. The conception of science as the proud production of a nation so closely resembled the Blut und Boden idea of Aryan physics, that Western scientists could hardly profess it any longer in its old, bombastic manner. National pride in science did not disappear with the Second World War, but its expression now had to avoid resemblance to the Nazi belief-system. In a 1941 war pamphlet, Julian Huxley denounced the University of Heidelberg's inscription 'To the German Spirit' as a sign of perverted science. What had been liberal and progressive one century earlier was now associated with reactionary evil (Huxley 1941, p. 20).

\section{Science as European}

Socialist scientists dominated much of the public discussion of science up to and during the Second World War, but their conception of scientific internationalism was not the only one around. In the same period, other views were voiced, some of which presented science as an explicitly European endeavour. Already during the Great War, for example, Einstein had co-authored a 'Manifesto to the Europeans', which portrayed science as a major constituent of a comprehensively European civilization. Scientists should retain their loyalty to this common culture and, Einstein warned, not lapse into antagonistic nationalisms (Nicolai et al. 1996). The French intellectual, Julien Benda, voiced a similar view in his Discourse à la Nation Européenne (Address to the European Nation) in 1933. Benda distinguished two European intellectual traditions. One was rooted in German romanticism and expressed itself in heroic art. This tradition stressed the uniqueness of national cultures and led to disunity and strife. The other was the tradition of Greek and French rationalism, that flourished in modern science and united people through its supranational character. The Europe that Benda preferred, Francophile despite himself, was based on the latter, 'scientific' tradition (Benda 1933).

Both Einstein and Benda explicitly identified science with Europe, but they did so in order to reject nationalist perspectives rather than a more global vision. What they attributed to science were anti-nationalist and internationalist qualities, and in this sense their views were not far removed from those of the socialist

\footnotetext{
25 Universalism was one of Merton's norms.
} 
internationalists. Their association of science with Europe was opposed to the level of nations instead of to the level of the world as a whole.

A turn towards a European conception of science that was decidedly not global took place in the historiography of science during the early post-war years, and this turn was an explicit reaction against the prevailing socialist-internationalist ideas. Socialist scientists, when they took to writing history, tended to take a global perspective, not viewing science as the product of a particular civilization, but as a human faculty common to all societies from prehistory onwards (e.g. Bernal 1986, pp. 65-89). This view corresponded with the socialist conception of science not as a particular cultural product, but as a universal instrument to solve practical problems.

A new generation of historians of science argued against this socialistinternationalist conception. For Herbert Butterfield and Alexandre Koyré, the socialist view reduced science to mere technology, ignoring the intellectual dimensions that were at the core of scientific endeavour. In their view, the history of science was to become a history of ideas. According to Koyré, great scientific innovations were 'made not by engineers and craftsmen, but by men who seldom built or made anything more real than a theory' (Koyré 1989, p. 121). ${ }^{26}$ The key defining moment in this new intellectual history of science was the Scientific Revolution - a new concept that soon became the major focus in the historiography of science (Butterfield 1949, p. viii). ${ }^{27}$ The theoretical transformations of sixteenth and seventeenth century astronomy and mechanics came to count as the pivotal developments that created not just modern science, but modernity itself. Achievements in medieval physics, which Pierre Duhem had proposed as equally revolutionary, were now reduced to 'preparations'. Developments in eighteenth and nineteenth-century chemistry and biology became 'postponed' elaborations. Prehistory and twentieth century science all but disappeared from view.

This chronological restriction was accompanied by a geographical constraint. The dismissal of the Middle Ages entailed a neglect of the many Islamic scholars of this period. It also resulted in the exclusion of the most important scientific developments in China, which were taken to have occurred before 1600. At the same time, the treatment of eighteenth and nineteenth century achievements as derivative reduced interest in Russia, the U.S. and Japan. A glance at the protagonists in Koyré's From the Closed World to the Infinite Universe (1957) reveals an entirely European cast, and the same is true for the main figures in Butterfield's The Origins of Modern Science (1949) (Koyré 1957; Butterfield 1949). Butterfield did devote one chapter to what he called 'Universal History', borrowing Ranke's term, in which he took a step back in order to assess the place of his events within the whole history of mankind. But this brief historical excursion beyond early modern Europe only served to legitimate the relevance of his chronological and geographical priorities.

\footnotetext{
26 For similar objections, see (Koyré 1957, p. vii).

27 On the invention of the Scientific Revolution, see (Cunningham and Williams 1993). On Butterfield: (Jardine 2003). See also (Shapin 1992, pp. 340-342).
} 
The scientific revolution we must regard (...) as a creative product of the West-depending on a complicated set of conditions which existed only in Western Europe. (Butterfield 1949, p. 139)

The view of science as a uniquely European product quickly eclipsed the socialist conception. Historians like A. Rupert Hall and Charles Gillispie endorsed it in their influential work, the latter combining it with swipes at 'the East', which had not produced modern science and could not be entrusted with its atomic products (Hall 1954; Gillispie 1960, p. 9). ${ }^{28}$ Such views were further sustained through the professionalization of the history of science in the first post-war decades. Many of the authors just mentioned were the occupants of the first professorial chairs in the field, established at leading universities such as Princeton, Cambridge, and Paris. From there, the European view came to be the standard in historical teaching and research.

But the shift away from socialist views of science was also encouraged by the political climate (Werskey 1988, pp. 281-289; McGucken 1978). With the onset of the Cold War, socialist ideals of scientific government and planning quickly became associated with coercion and totalitarianism. Bernal's admiration of the Soviet Union put him increasingly on the political fringe. Meanwhile attacks on German ideological physics backfired against left-wing scientists after the Lysenko affair: now ideological perversions were featured in socialism as well (Jones 1979). This shift of political fortunes was clearly visible in the philosophy of science. In the United States, intense left-wing political engagement gave way to a conception of the field as completely depoliticized - a transformation that was partly effected by McCarthyite intimidations (Reisch 2005). ${ }^{29}$ Developments in the history of science followed a similar path, for example in the History of Science Committee which established the first position in the field at Cambridge University. Initiated by Needham and friends in 1936, the committee became dominated by anti-Marxists in subsequent years, and eventually appointed Rupert Hall. The orientation of the field that resulted from this switch was decidedly anti-socialist. Links with social and economic history were severed, relations to the (newly depoliticized) philosophy of science were reinforced, and modern science was presented as the product of a single revolution-mankind needed no more. ${ }^{30}$ In the same process, science was reconceptualized from a global endeavour to a European production.

Finally, the European conception of science also spread beyond the disciplinary boundaries of the history of science. It was adopted in many general history textbooks, often designed for 'Western Civilization' courses, standard in American university curricula. And while the historiography of science continued to develop

\footnotetext{
28 Interestingly, this historiography was combined with remnants of the global outlook to produce a vast body of work on the question of why the Scientific Revolution had occurred first in Europe. Joseph Needham's post-war studies are early examples of this tradition; a recent synthesis of it is (Huff 1993).

29 The Cold War also evoked alternative responses. After the atomic bomb, many scientists called for sharing its knowledge internationally. This response, partly rooted in socialist views, developed into new expressions of internationalism in the volume One World or None, the Einstein-Russell manifesto, and the Pugwash conferences. See (Boyer 1985).

30 See (Mayer 2000a, b), and, on the political implications, (Mayer 2004).
} 
after 1960, going through changes from the Kuhnian revolution to the 'local turn', in these general texts, the early Cold War view proved remarkably persistent. My own copy of Palmer and Colton's History of the Modern World (8th edn., 1995) contains one chapter devoted to science, which indeed covers the Scientific Revolution, and draws mainly upon the 'older but still valuable' works of Koyré, Butterfield, and Rupert Hall. Newer social histories of science are labelled 'provocative studies' and one of the most cogent critiques of the intellectualist tradition, Leviathan and the Air-pump, appears under the history of technology (Palmer and Colton 1995, p. 1136). It is this enduring widespread adaptation that makes the notion of science as European, despite fundamental and continued challenges, still so common and recognizable today - and available to Euro-enthusiasts like the Crown Prince of the Netherlands. $^{31}$

\section{Conclusion}

In a recent essay, Lorraine Daston has argued that a main function of the history of science since the Enlightenment has been 'European self-portraiture' (Daston 2006). It is instructive to see whether the changing (historical and non-historical) conceptions of science reviewed in this article fit her general picture. Some qualifications can be made. It may be asked whether in the eighteenth century, science was always portrayed as European, rather than 'Western' or belonging to 'the civilized world'. And it could be added that in the nineteenth century, national self-portraiture was at least as important a function of discourse on science. But besides these minor border disputes, it seems that the general contours of the several maps of science outlined here do coincide with Daston's. Since the Enlightenment, science has been associated with modernity, and modernity with 'civilization', 'Christendom', and 'Europe'. Even during times when science was strongly identified with nationhood, it was still understood that non-European nations (apart from the US and some others) were of second rate importance, as was evident in Fritz Haber's remark about Siam.

There are, however, two main exceptions. The identification of science with Europe was not made by the socialist internationalists of the 1920s through 1940s, and is also refuted by today's localist historiography-as Daston herself indicates (Daston 2006, p. 532). For the latter reason, it is alarming that the conception of science as European is so enthusiastically embraced by current EU promoters. It is alarming, not because that conception is wrong (it is hard to speak about right and wrong geographical delineations after reviewing so many of them), nor just because it is outmoded, but because it carries with it the political overtones of the colonial era as well as the Cold War. What was once crafted to legitimize European imperialism and later enhanced to combat socialist worldviews is now being presented as part of a shared European culture. But it should not be accepted as such. Our times of globalization and intensifying cultural encounters are different

\footnotetext{
31 Prince Willem-Alexander has a university degree in history.
} 
than those that gave rise to the European picture-and they ask for a different history and geography of science.

Acknowledgements This article originated as a keynote lecture at the inaugural conference of the European Society for the History of Science at the University of Maastricht, on 4 November 2004. I thank Brigitte Schröder, Harmke Kamminga, Anna Mayer, Margaret Meredith, Steven Shapin, my Maastricht colleagues, and Minerva's subsequent editors and anonymous referees for invaluable comments and criticisms.

Open Access This article is distributed under the terms of the Creative Commons Attribution Noncommercial License which permits any noncommercial use, distribution, and reproduction in any medium, provided the original author(s) and source are credited.

\section{References}

Benda, Julien. 1933. Discours à la Nation Européenne. Paris: Gallimard.

Bensaude-Vincent, Bernadette. 1987. Langevin, 1872-1946: Science et Vigilance. Paris: Belin.

Bernal, John Desmond. 1939. The social function of science. London: George Routledge.

Bernal, John Desmond. 1986. Science in history: Volume 1: The emergence of science. Cambridge, MA: MIT Press.

Boyer, Paul. 1985. By the Bomb's early light. New York: Pantheon Books.

Bray, Francesca. 1996. Joseph Needham, 9 December 1900-24 March 1995. Isis 87 (2): 312-317.

Butterfield, Herbert. 1949. The origins of modern science. New York: Macmillan.

Cahan, David. 1989. An Institute for an Empire: The Physikalisch-Technische Reichsanstalt 1871-1918. Cambridge: Cambridge University Press.

Crawford, Elisabeth, Terry Shinn, and Sverker Sörlin (eds.). 1993. Denationalizing science: The contexts of international scientific practice. Dordrecht: Kluwer Academic.

Crosland, Maurice. 1995. Relationships between the Royal Society and the Adadémie des Sciences in the Late Eighteenth Century. Notes and Records of the Royal Society 59 (1): 25-34.

Crowther, James Gerald, Osbert John Radcliffe Howarth, and Dennis P. Riley. 1942. Science and world order. Harmondsworth and New York: Penguin Books.

Cunningham, Andrew, and Perry Williams. 1993. De-centering the "big picture": "The origins of modern science" and the modern origins of science. British Journal for the History of Science 26 (4): 407-432.

Daston, Lorraine. 1990. Nationalism and scientific neutrality under Napoleon. In Solomon's house revisited: The organization and institutionalization of science, ed. Tore Frängsmyr, 95-115. Canton, MA: Science History Publications.

Daston, Lorraine. 1991. The ideal and reality of the republic of letters in the enlightenment. Science in Context 4 (2): 367-386.

Daston, Lorraine. 1998. The academies and the unity of knowledge: The disciplining of the disciplines. Differences 10 (23): 67-86.

Daston, Lorraine. 2006. The history of science as European self-portraiture. European Review 14 (4): 523-536.

de Beer, Gavin. 1960. The sciences were never at war. London etc.: Thomas Nelson and Sons.

de Wilde, Rein, and Geert Somsen. forthcoming. Government as scientific process in H.G. Wells' World State. In Pursuing the unity of science: Scientific practice, ideology between the Great War and the Cold War, ed. Harmke Kamminga, and Geert Somsen. Aldershot: Ashgate Publishing.

Edgerton, David. 1966. British scientific intellectuals and the relations of science, technology and war. In National military establishments and the advancement of science and technology. Studies in 20th century history, ed. P. Forman, and J.M. Sanchez-Ron, 1-35. Dordrecht: Kluwer Academic.

Eijkman, Pieter Hendrik. 1910. l'Internationalisme Médical. La Haye: Bureau Préliminaire de la Fondation pour l'Internationalisme.

Eijkman, Pieter Hendrik. 1911. l'Internationalisme Scientifique. La Haye: Bureau Préliminaire de la Fondation pour l'Internationalisme. 
Fell, Ulrike. 2002. Die Chemiker im Frankreich der Dritten Republik. Die Doppelte Konstruktion von Nationaler und Professioneller Identität. In Wissenschaft und Nation in der Europä̈schen Geschichte, ed. Ralph Jessen, and Jakob Vogel, 115-142. Frankfurt: Campus Verlag.

Forman, Paul. 1973. Scientific internationalism and the Weimar physicists: The ideology and its manipulation after World War I. Isis 64 (2): 151-180.

Galison, Peter. forthcoming. Meanings of scientific unity: The law, the orchestra, the pyramid, quilt, and ring. In Pursuing the unity of science: Scientific practice, ideology between the Great War and the Cold War, ed. Harmke Kamminga, and Geert Somsen. Aldershot: Ashgate Publishing.

Gillispie, Charles Coulston. 1960. The edge of objectivity: An essay in the history of scientific ideas. Princeton: Princeton University Press.

Goldgar, Anne. 1995. Impolite learning: Conduct and community in the republic of letters, 1680-1750. New Haven: Yale University Press.

Golinski, Jan. 1998. Making natural knowledge: Constructivism and the history of science. Cambridge: Cambridge University Press.

Goodman, Dena. 1994. The republic of letters: A cultural history of the French enlightenment. Ithaca: Cornell University Press.

Goschler, Constantin. 2002. Deutsche Naturwissenschaft und Naturwissenschaftliche Deutsche. Rudolf Virchow und die "Deutsche Wissenschaft". In Wissenschaft und Nation in der Europäischen Geschichte, ed. Ralph Jessen, and Jakob Vogel, 97-114. Frankfurt: Campus Verlag.

Grau, Conrad. 2000. Die Preußische Akademie und die Wiederanknüpfung internationaler Wissenschaftskontakte nach 1918. In Die Preußische Akademie der Wissenschaften zu Berlin 19141945, ed. Wolfram Fischer, 279-315. Berlin: Akademie-Verlag.

Hall, A. Rupert. 1954. The scientific revolution, 1500-1800: The formation of the modern scientific attitude. London: Longmans, Green and Co.

Harwood, Jonathan. 1987. National styles in science. Genetics in Germany and the United States between the World Wars. Isis 78 (3): 390-414.

Hill, Archibald Vivian. 1937. The humanity of science. In What science stands for, ed. John Boyd Orr, et al., 30-38. London: George Allen \& Unwin.

Hollinger, David. 1983. The defense of democracy and Robert K. Merton's formulation of the scientific Ethos. Knowledge and Society 4: 1-15.

Home, Roderick W. 2002. The royal society and the Empire: The Colonial and Commonwealth Fellowship Part 1. 1731-1847. Notes and Records of the Royal Society 56 (3): 307-332.

$\mathrm{HRH}$ the Prince of Orange. 2006. Presentation speech. In Wetenschap en Samenleving. Erasmusprijs 2005-Science and Society: Erasmus Prize 2005, ed., 101-103. Amsterdam: Praemium Erasmianum Foundation.

Huff, Toby E. 1993. The rise of early modern science: Islam, China, and the West. Cambridge: Cambridge University Press.

Huxley, Julian. 1941. Argument of blood. London: Macmillan War Pamphlets.

Jardine, Nick. 2003. Whigs and stories. Herbert Butterfield and the historiography of science. History of Science 41 (2): 125-140.

Jessen, Ralph, and Jakob Vogel. 2002. Einleitung. Die Naturwissenschaften und die Nation. Perspektiven einer Wechselbeziehung in de Europäischen Geschichte. In Wissenschaft und Nation in der Europäischen Geschichte, ed. Ralph Jessen, and Jakob Vogel, 7-37. Frankfurt: Campus Verlag.

Johnson, Jeffrey Allan. 1990. The Kaiser's chemists: Science and modernization in imperial Germany. Chapel Hill: University of North Carolina Press.

Jones, Greta. 1979. British scientists, Lysenko, and the Cold War. Economy and Society 8: 26-58.

Jones, H.Spencer. 1960. The early history of ICSU 1919-1946. ICSU Review 2: 169-187.

Kevles, Daniel. 1971. "Into Hostile Political Camps": The Reorganization of International Science in World War I. Isis 62 (1): 47-60.

Koch, Paul, and Jennifer Platt. 1993. Migration and the denationalization of science. In Denationalizing science: The contexts of international scientific practice, ed. Elisabeth Crawford, Terry Shinn, and Sverker Sörlin, 133-152. Dordrecht: Kluwer Academic.

Koyré, Alexandre. 1957. From the closed world to the infinite universe. Baltimore and London: The Johns Hopkins University Press.

Koyré, Alexandre. 1989. Galileo and Plato. Reprinted in The history of sciences: The French debate, ed. Pietro Redondi, and P.V. Pillai, 120-145. New Delhi: Orient Longman.

Krige, John, and Kai-Henrik Barth. 2006. Global power knowledge. Science and Technology in International Affairs. Osiris 21 (second series). 
Kuznick, Peter J. 1987. Beyond the laboratory: Scientists as political activists in 1930s America. Chicago: University of Chicago Press.

Lecourt, Dominique. 1993. Repenser la science. Le Monde Diplomatique 40: 25.

Lenoir, Timothy. 1997. Instituting science: The cultural production of scientific disciplines. Stanford: Stanford University Press.

Livingstone, David. 2003. Putting science in its place: Geographies of scientific knowledge. Chicago: University of Chicago Press.

Low, Morris. 1998. Beyond Joseph Needham. Science, Technology, and Medicine in East and Southeast Asia. Osiris 13 (second series): 1-8.

Lyons, Henry (ed.). 1935. The Second General Assembly of the International Council of Scientific Unions Held at Brussels, July 9th to 13th, 1934: Reports of Proceedings. London: [s.n.].

MacLeod, Roy (ed.). 1996. Public science and public policy in Victorian England. Aldershot: Ashgate.

MacLeod, Roy (ed.). 2000a. Nature and Empire. Science and the Colonial Enterprise. Osiris 15 (second series).

MacLeod, Roy. (ed). 2000b. The 'Creed of Science' in Victorian England. Aldershot etc.: Ashgate.

MacLeod, Roy. 2000c. Der Wissenschaftliche Internationalismus in der Krise: Die Akademien der Alliierten und ihre Reaktion auf den Ersten Weltkrieg. In Die Preußische Akademie der Wissenschaften zu Berlin 1914-1945, ed. Wolfram Fischer, 317-349. Berlin: Akademie-Verlag.

MacLeod, Roy. 2005. Science in Latin-American contexts-Historical studies. Special issue of Science in Context 18 (2): 173-315.

Mayer, Anna-K. 2000a. Setting up a discipline: Conflicting agendas of the Cambridge History of Science Committee, 1936-1950. Studies in the History and Philosophy of Science 31 (4): 665-689.

Mayer, Anna-K. 2000b. "A Combative Sense of Duty": Englishness and the scientists. In Regenerating England: Science, Medicine and Culture in Inter-War Britain, ed. Christopher Lawrence, and AnnaK. Mayer, 67-106. Amsterdam and Atlanta: Rodopi.

Mayer, Anna-K. 2004. Setting up a discipline, II: British History of Science and "the End of Ideology", 1931-1948. Studies in the History and Philosophy of Science 35 (1): 41-73.

McClellan III, James E., and Harold Dorn. 1999. Science and technology in world history: An introduction Baltimore: The Johns Hopkins University Press.

McCormach, Russell. 1974. On academic scientists in Wilhelmian Germany. Daedalus 103 (3): 157-171.

McGucken, William. 1978. On freedom and planning in science: The Society for Freedom in Science, 1940-1946. Minerva 16 (1): 42-72.

McGucken, William. 1984. Scientists, society, and state: The Social Relations of Science Movement in Great Britain 1931-1945. Columbus: Ohio State University Press.

Metzler, Gabriele. 2000. Internationale Wissenschaft und Nationale Kultur: Deutsche Physiker in der Internationalen Community, 1900-1960. Göttingen: Vandenhoeck and Ruprecht.

Mikami, Yoshio. 1914. On the Japanese theory of determinants. Isis 2 (1): 9-36.

Nicolai, Georg Friedrich, Albert Einstein, and Wilhelm Förster. 1996. Aufruf an die Europäer. In The collected papers of Albert Einstein Vol. 6: The Berlin Years: Writings, 1914-1917, ed. Anne J. Kox, Martin Klein, and Robert Schulmann, 69-71. Princeton: Princeton University Press.

Office for Official Publications of the European Communities. 2006. Teaching and learning: Towards the learning society-European Commission White Paper on Education and Learning. Luxembourg.

Oosterhoff, J.L. 1984. De Opkomst van een "Vaderlandsche Natuurkunde" aan de Leidse Universiteit in de Tweede Helft van de Negentiende Eeuw. In Een Universiteit Herleeft: Wetenschapsbeoefening aan de Leidse Universiteit vanaf de Tweede Helft van de Negentiende Eeuw, ed. W. Otterspeer, 103124. Leiden: Brill Universitaire Pers.

Ophir, Adi, and Steven Shapin. 1991. The place of knowledge: A methodological survey. Science in Context 4 (1): 3-21.

Otterspeer, Willem, and Joke Schuller tot Peursum-Meijer. 1997. Wetenschap en Wereldvrede: de Koninklijke Akademie van Wetenschappen en het Herstel van de Internationale Wetenschap tijdens het Interbellum. Amsterdam: Koninklijke Nederlandse Akademie van Wetenschappen.

Partington, John S. 2003. Building cosmopolis: The political thought of H. G. Wells. Aldershot: Ashgate.

Petitjean, Patrick. (unpublished paper). Sur Quelques Aspects des Sociabilités Scientifiques entre Cambridge et Paris dans les Années 1930 et 1940.

Palmer, Robert Roswell, and Joel Colton. 1995. A history of the modern world, 8th ed. New York: McGraw-Hill.

Rasmussen, Anne. 1990. Jalons pour une Histoire des Congrès Internationaux au XIX ${ }^{\mathrm{e}}$ Siècle: Régulation Scientifique et Propagande Intellectuelle. Relations Internationales 62: 115-133. 
Reisch, George A. 2005. How the Cold War transformed philosophy of science: To the icy slopes of logic. New York: Cambridge University Press.

Ruska, Julius. 1913. Die Mineralogie in der arabischen Literatur. Isis 1 (3): 341-350.

Salmón, Fernando, and Rafael Huertas. forthcoming. Unifying science against Fascism: Neuropsychiatry and medical education in the Spanish Civil War (1936-1939). In Pursuing the unity of science: Scientific practice, ideology between the Great War and the Cold War, ed. Harmke Kamminga, and Somsen Geert. Aldershot: Ashgate Publishing.

Salomon, Jean-Jacques. 1971. The internationale of science. Science Studies 1 (1): 23-42.

Sarton, George. 1913. l'Histoire de la Science. Isis 1 (1): 3-46.

Sarton, George. 1919. War and civilization. Isis 2 (2): 315-321.

Schaffer, Simon. 2000. Modernity and metrology. In Science and power: The historical foundations of research policies in Europe, ed. Office for Official Publications of the European Communities, 7191. Luxembourg.

Schröder-Gudehus, Brigitte. 1966. Deutsche Wissenschaft und Internationale Zusammenarbeit, 19141928: Ein Beitrag zum Studium Kultureller Beziehungen in Politischen Krisenzeiten. Genève: Dumaret \& Golay.

Schröder-Gudehus, Brigitte. 1978. Les Scientifiques et la Paix: la Communauté Scientifique Internationale au Cours des Années 20. Montréal: Les Presses de 1'Université de Montréal.

Schroeder-Gudehus, Brigitte. 1990. Les Congrès Scientifiques et la Politique de Coopération Internationale des Académies des Sciences. Relations Internationales 62: 135-148.

' Science and world order'. 1942. The Advancement of Science 2: 1-120.

Shapin, Steven. 1998/1999. Vorurteilsfreie Wissenschaft und Gute Gesellschaft: Zur Geschichte eines Vorurteil. Transit: Europäische Revue 16: 51-63.

Shapin, Steven. 1992. Discipline and bounding: The history and sociology of science as seen through the externalism-internalism debate. History of Science 30 (4): 333-369.

Shapin, Steven. 1995. Here and everywhere: Sociology of scientific knowledge. Annual Review of Sociology 21: 289-321.

Smith, David Eugene. 1913. The geometry of the Hindus. Isis 1 (2): 197-204.

Somsen, Geert. 2001. Waardevolle Wetenschap: Bespiegelingen over natuurwetenschap, moraal en samenleving in de aanloop naar de Doorbraak-beweging. Gewina 24 (4): 207-224.

Speeckaert, Georges Patrick. 1957. The 1978 international organizations founded since the congress of Vienna: Chronological list. Brussels: Union of International Associations.

Stratton, Frederick John Marrian. (ed.). 1937. The Third General Assembly of the International Council of Scientific Unions held at London, April 24th to May 3rd 1937: Reports of Proceedings. London: [s.n.].

Thackray, Arnold, and Robert K. Merton. 1972. On discipline building: The paradoxes of George Sarton. Isis 63 (4): 473-95.

Theunissen, Bert. forthcoming. Unifying science and human culture: The promotion of the history of science by George Sarton and Frans Verdoorn. In Pursuing the unity of science: Scientific practice and ideology between the Great War and the Cold War, ed. Harmke Kamminga, and Geert Somsen. Aldershot: Ashgate Publishing.

Turner, Frank. 1980. Public science in Britain, 1880-1919. Isis 71 (4): 589-608.

van Berkel, Klaas. 1998. Citaten uit het Boek der Natuur: Opstellen over Nederlandse Wetenschapsgeschiedenis. Amsterdam: Bert Bakker.

van Deventer, Charles M. 1887. Nederlandsche Scheikunde. De Nieuwe Gids 2: 144-47.

van Lunteren, Frans H. 2004. Wetenschap voor het Vaderland. J.D. van der Waals en de Afdeling Natuurkunde. In De Akademie en de Gouden Eeuw, ed. Klaas van Berkel, 43-106. Amsterdam: Koninklijke Nederlandse Akademie van Wetenschappen.

Veblen, Thorstein. 1918. The higher learning in America. A memorandum on the conduct of universities by Business Men. New York: B.W. Huebsch.

Visser, Robert P.W. 1991. Het "Nederlandsch Natuur- en Geneeskundig Congres" over de Relatie Natuurwetenschap en Samenleving, 1887-1900. In Balans en Perspectief van de Nederlandse Cultuurgeschiedenis: de Productie, Distributie en Consumptie van Cultuur, ed. J.J. Kloek, and W.W. Mijnhardt, 37-48. Amsterdam and Atlanta: Rodopi.

von Ungern-Sternberg, Jürgen, and Wolfgang von Ungern-Sternberg. 1996. Der Aufruf 'An die Kulturwelt!': das Manifest der 93 und die Anfänge der Kriegspropaganda im Ersten Weltkrieg. Stuttgart: Franz Steiner Verlag.

Werskey, Gary. 1971. British scientists and "Outsider" Politics, 1931-1945. Science Studies 1 (1): 67-83. 
Werskey, Gary. 1988. The visible college: A collective biography of British scientists and socialists of the 1930s. London: Free Association Books.

Whetham, Catherine Durning, and William Cecil Dampier Whetham. 1913. Three English men of science. Isis 1 (2): 215-218.

White, Andrew D. 1893. A history of the warfare of science with theology in Christendom, vol. 2. New York: Appleton.

Widmalm, Sven. 1995. Science and neutrality: The Nobel Prizes of 1919 and Scientific Internationalism in Sweden. Minerva 33 (4): 339-360.

\section{Author Biography}

Geert Somsen is assistant professor in history of science. After a $\mathrm{PhD}$ in the history of chemistry, his current work focuses on socialist conceptions of science in the twentieth century and on scientific internationalism. With Harmke Kamminga, he edited Pursuing the Unity of Science: Scientific Practice and Ideology between the Great War and the Cold War (Aldershot: Ashgate Publishing, forthcoming). 